Вања С. Станишић

Филолошки факултет

КатеАра за српски језик с јужнословенским језицима

\title{
ПРОСТОР И ВРЕМЕ У СТРУКТУРИ ПИСМА
}

Апстракт: Писменост представьь једну од најважнијих одлика чивилизащије. То је поуздан доказ да је неки народ изишао из предисторије и ступио у период свога историјског развоја. Грабичка порука одређене чивилизачије по правилу може бити прочитана и демифрована зато ито се ослата на систем одређенога језика. Језички критериј, у том смислу, представља карику која повезује писмо и щивилизачију. И поред тога, у науци се може поставити питате да ли се писмо рађ а истовремено с иивилизащијом, баш као ито се цивилизащија рађа с писмом. При одговору на то питатье неопходно је имати у виду чињенииу да писмо представља двострану појаву, чију унутрашну структуру одређује језичка основа, а сповашну форму културна историја.

Кључне речи: типологија и развој писма, класификаиија писмених система, категорија простора и категорија времена.

Наука о писму започиње своју историју при крају XIX века као помоћна историјска дисциплина, тачније као једна област културне историје, највише заокупьена пореклом, дешифровањем и еволуцијом старих писама. Такав приступ одражава јеАна оА првих и најутицајнијих књига о писму, написана у строгом научном духу, Алфабет Исака Тејлора (1883), у којој је била формулисана трипартитна типолошка и стадијална подела писмених система на иртежкно, слоговно и алфабетско писмо (Бугарски 1996: 15; Daniels 1996: 6; Арукер 2006: 31). Ао њеног преображаја у самосталну научну дисциплину дошло је средином XX в., с појавом књиге Студија о писму (основи граматологије) америчког семитомога Џеја Гелба (1952; 1963 [Гемьб 1982]). По методу и по имену уско повезана с модерном науком о језику, ова прва семиотичка студија о писму по 
општем мишьењу преАставља преломни моменат у научном схватању теорије писма (Зиндер 1987: 12). У последњим деценијама ХХ в. управо на Гелбовим идејама о упоредно-типолошком приступу еволуцији писма у низу радова разрађује се мингвистичка теорија писма, ${ }^{1}$ у којима је, уместо историјског описа појединих писмености као дела културне историје, примењен структурни опис „писмених система”.

Методолошко приближавање науке о писму и науке о језику почива на чврстој вези између језика и писма, која је у науци о писму откривена и разрађена управо применом читавог низа операционацних појмова и техника мингвистичке анализе (Станишић 2003: 255-256). Изворно фонолошки појмови, као што су опозиција, корелачија, неутрализащија итА., који се данас срећу у свим областима мингвистике, доказују, по речима ВАадимира Константиновича Журавьова (1986: 204), ону фундаменталност и ону концептуалну

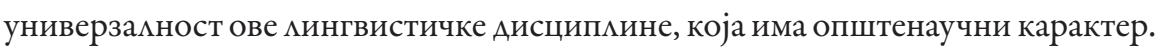

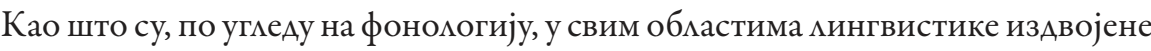
и дефинисане њихове основне структурне јединице (фон - алофон-фонема, мор $\varnothing$ - аломор $\oint$-морфема итА.), тако су и у науци о писму основне структурне јединице граф - алограф - графема, док је сам назив граматологија и формално и функционално подударан називу филологија (упор. Daniels 1990; 1996: 1-18; Кондратов 2007: 19-20).

Иако је у теоријским радовима о писму термин граматологија у почетку наишао на доста опречан пријем и био чак третиран као алтернатива графичке мингвистике, која се тада уобличавала, тако да га је и сам Гелб био изоставио из наслова другог издања своје књиге 1963. године (Зиндер 1987: 12), с временом је дошио до задовољавајућег разграничења тих назива. Оно се савршено поАударило с језикословном поделом на филологију и мингвистику, тако што се назив граматологија показао као најзахвацнији за најшире замишьену науку о писму и писању уопште. Насупрот њој, графичка лингвистика ики графомингвистика представља подврсту ове опште науке о писму, која изучава само процес писања, тј. графички пренос језичке поруке (Žagar 2007: 27-28).

Питање односа фонологије и граматологије подразумева и разјашњење односа језика и писма. Захваљујући парамемизму између писма и језика, и

\footnotetext{
${ }^{1}$ УП. нпр. Историју и теорију графемике Т. Амирове (1977) и Оглед опите теорије писма Аава Зиндера (1987) и тамо наведену бројну старију митературу, као и веома утицајну студију Џона Аефрансиса (DeFrancis 1989) Визуелни говор, која својим називом симболизује став о хијерархијском односу језика и писма.

${ }^{2}$ Сам назив „писмени системи” као ознаку теоријског приступа писму у насловима својих студија истичу Sampson 1985 (1987); Coulmas 1989, 2003; Daniels/Bright 1996; Rogers 2005.
} 
у науци о писму уведен је читав низ операционалних појмова и поступака лингвистичке анализе. Методолошко приближавање науке о писму и науке о језику почива на чврстој вези између језика и писма. Аингвистички приступ писму скренуо је пажњу на постојање истоветне фундаменталне Аингвистичке подеме на површинску и дубинску структуру, тј. подеме на „план израза” и „План садржаја” (уп. Станишић 2009: 81-82). Писмо такође има Авострану знаковну природу - унутрашғы структуру, коју условњавају језичке појаве, и спољашъу форму - усмовњену културном историјом. Та Авострана природа писмених знакова омогућава разликовање генетских и структурних критерија у историји и типологији писма.

По својој двостраној природи писмо је, Аакме, у тесној вези како с језиком тако и с културном историјом. Парафразирајући Гелбове речи о цивилизацијском значају писма, амерички стручњак Питер Ааниелс истиче следеће: „Будско Аруштво је оАређено посредством језика, а цивилизација је одређена преко писма" (Daniels 1996: 1). Из овога може да проистиче не само тврдња како је језик примаран, а писмо секундарно, него и то Аа писмо пореА своје комуникативне улоге преАставња и јеАну оА најважнијих сповашњих оАлика неке цивилизације.

Поменути хијерархијски однос између језика и писма подразумева се и у најраспрострањенијој дефиницији писма, по којој је то средство комуникащије помоћу условно применених визуелних знакова које омогу ава преношете поруке у времену и простору (в. ФриАрих 1966: 31; Гемьб 1982: 23; Olson 1988: 1033; Зиндер 1987: 50; Бугарски 1996: 14). Међутим, схватањем писма само као среАства комуникације пренебрегава се, у суштини, његова културна димензија. Губи се из вида чињеница да писмо није само средство него и симбол који комуникацију смешта у одређене културне и цивилизацијске оквире.

Категорија времена (историјско памћење одређене цивилизације) губи се из вида и у широко распрострањеној типолошкој кмасификацији писмених система извршеној пре свега на основу категорије простора, тј. према начину вршења комуникације међу члановима одређене заједнице - по типу односа између графичких и језичких јединица. Аингвистичка подела „на план израза” и „План садржаја” овде се појавьује као критериј разграничења. У скмаду с тим, разликују се Ава основна типа: појмовно писмо и гласовно писмо - идеографија и фонографија по Ф. де Сосиру, који је увео ту поделу (уп. Harris 2000: 138), ими семасиографија и глотографија, како је касније преименована - оА којих се прво доводи у везу с планом саАржаја језичких јединица (под којима се подразумевају језичке јединице вишег нивоа), Аок би друго било усмерено на 
план израза језичких јединица, дакме на гласовну структуру језика (Зиндер 1987: 48; Pulgram 1976; Cardona 1986: 34; Sampson 1987; Haarmann 1991: 147; Olson 1997).

Ова Ава типа нису исте старине. Аобро је познато како је појмовно писмо старије, Аа су све аутохтоне писмености биме појмовне (цртежне) и да је кинеско писмо једино такво писмо које још постоји. Због тога је у најужој вези с овом поделом и широко распрострањено уверење како је ова подела истовремено евокутивна и хијерархијска, Аа између њих пролази и граница између писма и претписмености. Ова битна структурна размика између појмовног и гласовног писма налази се у основи питања намене писма: какав се систем визуелне комуникације може назвати писмом и до које мере он треба да буде заснован на одређеном језику?

На схватању о писму као средству и огледалу језика почива и еволуционистичко тумачење развоја писма који почиње од ембрионалних цртежних облика преко старијег и млађег типа цртежног писма и завршава се алфабетом као најсавршенијим типом писма (Зиндер 1987: 11-15; Бугарски: 21-26; такође Coulmas 2003: 15-16).

Према још увек преовлађујућем мишљењу о пореклу гласовног писма, оно је настало еволуцијом из појмовног писма као последица ширења знања о природи језика и открића језичких јединица мањих оА речи. У том смислу, откриће ацфабета обично се сматра „највећим достигнућем у културној историји човечанства, које је тако добимо просто и ефектно средство графичке фиксације говора" (Гемьб 1982: 75; Diringer 1985: 13; Pulgram 1976; ГамкремиАзе 1989: 214). У скмаду с тим, такође се сматра како је у историји писма ацфабет самостално откривен само једном, и то се остварење приписује или семитској писмености у целини или њеном најпознатијем деривату - грчком писму.

Како се види, еволуционистичко схватање хијерархијског односа између писма и језика, које влада у многим европским мингвистичким школама, у знатној мери почива на европоцентричком алфабетском графичком моделу. Њега је у науци о писму у великој мери својим ауторитетом наметнуо управо Гелб својом познатом хипотезом о једносмерном развоју писма (unidirectional development). Његово схватање еволуције писма представња у суштини теоријско осмишьавање поменуте типолошке кмасификације писма као универзалног једносмерног развојног процеса у три фазе: цртежно писмо $\rightarrow$ слоговно писмо $\rightarrow$ алфабет. У томе се могу препознати одјеци еволуционистичких схватања XIX столећа - у првом реду трипартитне и стадијанне подеме писмених система, која одражава културни прогрес, изнете у радовима 
Едварда Тајмора и Исака Тејмора. ${ }^{3}$ Комбинујући поменути еволуционизам с аристотеловским сурогационизмом, Гелб је ово наслеђе XIX столећа претворио у научну парадигму.

Спорне су, међутим, идеолошке импликације овога схватања, управо теза о алфабету као најсавршенијем типу писма. Ту је очигледно реч о пристрасном гледишту о културној супремацији Запада, чији корени сежу још дубње, у XVIII век, до епохе просветитеьства, очараног идејом прогреса и развоја ьудског сазнања. Еволуционистичко рангирање различитих типова писма према степену апстракције у европској фимософији најпре се среће код Вимијама Варбуртона. ${ }^{4}$ Европоцентрички карактер тога рангирања одражава подела Жан-Жака Русоа на „три начина писања”, који одговарају трима периодима у развоју ьудског Аруштва: 1) сликање објеката одговара „дивьим” народима (мексички хијероглифи); 2) конвенционално обележавање речи и целих реченица „варварским” народима (кинески знаци); 3 ) док би алфабет био одлика „просвећених" народа (Calvet 1996: 9). Продужетак оваквог схватања представњају величања алфабета (у многим студијама о писму) као производа напредне културе, својеврсне „менталне револуције” и „демократског писма”, које је настало у некаквој интернационацној, трговачкој и демократској среАини, какве су биле блискоисточни трговачки градови и античка Грчка (уп. Станишић 2002: 49). Из тога је проистекла и тзв. теорија рационалног избора (Rational Choice Theory), која ширење матиничког писма по читавом свету објашњава „супериорношћу” алфабетског система, ${ }^{5}$ пренебрегавајући притом чињеницу како је то ширење најчешће праћено политичком, економском и културном експанзијом моћних држава Запада (Coulmas 2003: 201; 2009: 5).

ГАедано у целини, Гелбова Граматологија преАставља завршницу једног периода развоја науке о писму и може се упоредити с местом и улогом Compendium-a Августа ШАајхера у мингвистици XIX века. Оба стручњака карактерише сличан телеолошки еволуционизам, који је у оба случаја доживео оштру критику. Етикета „pedigrée-теорија”, која је својевремено бима упућена Шیајхеровом делу, може се препознати и у савременој критици Гелбове теорије окарактерисане, између осталог, као „квазисоцијамни Аарвинизам” и „про-

${ }^{3}$ E. B. Tylor (1865), Researches into the Early History of Mankind and the Development of Civilization, London; I. Taylor (1883), Alphabet, London. Уп. такође Justenson/Stephens 1993: 2.

${ }^{4}$ W. Warburton (1741), The Divine Legation of Moses (в. Hamann 2008: 37-38)

${ }_{5}^{5}$ УП. о томе нпр. Gelb 1963: 203; Diringer 1968; J. Goody 1968 (Introduction in International Journal of the Sociology of Language); Mair 1996: 203; E. Havelock (2003), „Communication in History: Technology, Culture, Society”, The Greek Legacy, Boston: Allyn \& Bacon, 53-58). 
матински ацфабетски фетишизам". ${ }^{6}$ Међутим, оба стручњака поставила су научне парадигме у својим научним обцастима ${ }^{7}$ и означима прекретницу у дањем развоју историјске мингвистике, али и науке о писму. Упркос видним траговима и остацима ранијих епоха у схватању и тумачењу писма, Гелб је први објединио и повезао нове научне токове у тумачењу писма и засновао нову научну дисциплину, чврсто везану за језичке параметре.

Насупрот пристрасној тврдњи како су нека писма боља од Аругих, објективна је чињеница да одређена писма боње одговарају неким језицима, као што нпр. слоговно писмо добро функционише у свим оним језицима који имају ограничен број слогова и у којима се покмапају границе морфеме и слога, какав је случај управо са свим оним језицима света који и дање употребьавају своја слоговна писма (нпр. етиопски, брахми и јапанска кана). Распрострањено европоцентрично схватање о „супериорности” алфабетског писма, које у виду има само фонолошки план, пренебрегава неуспех алфабетизације кинеског језика и чињеницу да кинеско писмо има везе управо с вишим језичким јединицама, у односу на које Аалеко боње одговара кинеском језику од ацфабетског писма. Због свега тога, по речима Хенрија Роџерса, нема објективног критеријума за квалитативно упоређивање појединих писама. Својеврсно отварање очију у том смислу представња и тврдња Аејвида Олсона како се сваки систем писма оптимализује током времена - језик и писмо су тако чврсто повезани да се и писмо временом непрестано прилагођава датом језику, тако да се, на крају, може рећи како сваки систем писма одговара своме језику (Olson 1988; Rogers 1995: 36).

Па ипак, неоспорна је чињеница да су типологија писма и еволуција писма глобално паралелне, тј. Аа еволуција писма има у начелу једносмеран развој и да је конвенционализација писма - удањавање од цртежа уз споразумно задобијање чисто језичких вредности - битна одлика његове еволуције (Бугарски 1996: 45, 47). У том смислу, Гелб је изнео у основи тачну тврдњу како се ниједан већ алфабетизован систем није вратио на неку ранију цртежну фазу, једино што није могуће доказати како је такав развој у вези с цивилизацијским прогресом, јер пренебрегава се, међутим, чињеница Аа су све Аревне цртежне писмености остале неизмењене по структури током читавог постојања. Измене које је египатско писмо доживело током своје историје биме су само споњашње

${ }^{6}$ Battestini, Simon (1997). Ecriture et texte: Contribution africaine, Quebec: Les Presses de l'Université Laval, 285; Coulmas 2003: 15.

${ }^{7}$ У вези с квалификацијом Шиајхеровог дела као научне парадигме у индоевропеистици уп. К. Г. Красухин (2004), Аспекты индоевропейской реконструкиии, „Языки скавянской культуры”, Москва, 36. 


\section{Barва C. Станишић}

природе и у његовој структури се преко 2000 година није ништа битно мењацо. Исто важи и за кинеско писмо, најстарије од свих живих писмености, које без суштинских измена постоји већ преко 3000 година.

Традиционално еволуционистичко схватање писма као визуелне комуникације, које се временом преображава у „одраз” језика, у оквиру претписмене комуникације (Gelb 1963: 13; Coulmas 2003: 15; Fischer 2001: 13) обично укьучује појам тзв. предметног писма. У вези с њим, Гелб је унео врло важно разјашњење његовог статуса.

Споразумевања помоћу предмета, које се обично назива предметно писмо, носи у суштини погрешно име, пошто оно по Гелбовим речима (1963: 18) нема ништа заједничко с писмом. Будући да овај вид комуникације има чисто асоцијативни карактер, број визуелних знакова помоћу преАмета је неограничен. Један оА најпознатијих примера оваквог споразумевања који је ушао у светску књижевну баштину јесу тзв. скитски дарови, које спомиње Херодот $(I V, 131)$ у опису Ааријевог похода на Ските. Аобивши од скитских владара на Аар птицу, миша, жабу и пет стрела Аарије брзоплето закьучи како му Скити предају своје небо, земьу и воду и своје оружје, док је његов мудри саветник Гобрије препознао у томе претњу која гласи: „Ако се не претворите у птице и одлетите у небо, или се не сакријете у земьу попут мишева, или не поскачете у воду попут жаба, побићемо вас овим стрелама”. Овај пример на очигледан начин разоткрива слабу страну предметног писма, а управо двосмисленост његових знакова, која у датом контексту подсећа на пророчанства античких оракула („Ако Крез пређе реку Хацис пропашће велика држава”), која су постајала јасна тек онда када би се несрећа већ догодима (Martin 1990: 8).

Потпуна произвољност и чисто асоцијативни карактер чине „писмо преАмета” веома ограниченим среАством комуникације, које се практично своди само на помоћно меморијско средство. То је посредно и уопштено помоћно средство универзалне језичке комуникације и стога би му више одговарао назив говор него писмо предмета.

Фаворизовање схватања писма као визуелног облика језичке комуникације, могично укьучује у ову врсту општења и комуницирање помоћу предмета. Међутим, управо на овај вид комуникације могао би се применити назив визуелни говор, јер саАржи једну оА Аве основне комуникативне Аимензије самог

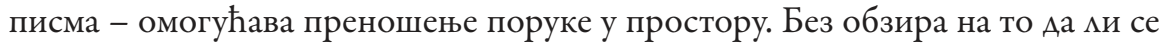
просторна димензија схвата као комуникација на Ааьину или само у простору, то је у суштини хоризонта нна комуникација, која се може назвати језиком 
или говором предмета. Вертикалну или временску димензију комуникације - која ће овај визуелни говор претворити у писмо - унео је знак на предмету.

Писмено споразумевање не остварује се посредством предмета, него помоћу знакова на њима. Суштинска новина у развоју писма, која је дошла с појавом цртежног писма, била је у томе што се њиме порука одваја од предмета и преноси на размичите материјаме за писање. Управо губњење преАметности, прелаз на материјал за писање представња, по речима Јоханеса Фрияриха (1966: 37), важан корак ка писму у уском смиску речи. Аобро је познато, такође, Аа је и сам назив за писмо у многим језицима првобитно означавао урезане знаке: уп. енгл. to write 'писати' - нем. reissen 'гребати', мат. scribere 'писати' - нем. kerben 'резати' итА. (Гельб 1982: 18). ОАговарајући индоевропски глаголски корен *(s) ĝreb[ [ $\left.{ }^{\mathrm{h}}\right]$ - дао је грч. $\gamma \rho \dot{\alpha} \phi \omega, \gamma p \dot{\alpha} \mu \mu \alpha$ 'писати, писмо', стенгл. screpan 'гребати', стсл. жръбии и прус. girbin 'број'. Ови називи тачно одговарају различитом времену појавьивања појединих индоевропских народа на историјској сцени потпуно је Аогично зашто међу наведеним примерима само у грчком налазимо значење „писмо”.

Ово питање илуструју и прасловенске „чрте и резе”, које и својим називом и својом функцијом јасно показују какав је био првобитни смисао урезаних знакова. Уопште, овај изванредни податак Црнорисца Храбра како Словени „немајући књига најпре 'чртама' и 'резама' читаху и гатаху док бејаху пагани”, а Аа су потом, „покрстивши се, почели да записују словенску реч грчким и матинским писмом", оАлично осветьава и питање односа између писма и цивилизације и разграничења између писма и претписма. Из Храбрових речи сазнајемо не само какав је био ступањ културе Старих Словена него и да најстарији словенски знаци нису били писмо. То је јасно из њихове функције и намене: глагол читати првобитно је означавао бројање ${ }^{8}$, Аок је гатағе бимо преАсказивање по резама, познато у обредно-магијској пракси многих народа (баш као и regiones римских аугура - обредни резови на жртвеној животињи - Станишић 2002: 44). Такви обредно-магијски знаци тачно одговарају доцивилизацијском ступњу развоја, у којем још увек нема ни књиге ни писма - појмова чији називи у прасловенском сведоче о контактима Старих Словена с народима који су већ знали и за књигу и за писмо. ${ }^{9}$

\footnotetext{
${ }^{8}$ Упор. старосл. чьтљ, чисти, число као и митав. skaitýti и староинд. cétati с општим значењем 'бројати, рачунати, познати, разумети, поштовати' (Этимологический словарь славянских языюов, 4, Москва 1977: *̌isti).

${ }^{9}$ Храброву тврдњу како пагански Словени не имъхж к[ъ]нигъ (што би значимо 'не имаху пuсма') потврђује и несловенско порекмо самих речи кънига, кънигъчиі - 'књижник' (уп. старотурк. *küinigči), као и боуквi, боукарь - 'граматик' (уп. готски bōka, bökareis). Што се тиче словенског
} 


\section{Bана С. Станишић}

Као што су САовени тек ступањем на историјску сцену почели да користе писмо, тако су исти пут развоја прошли и најстарији народи света, створивши писмо тек када су им нови, цивилизацијски услови живота наметнули ту потребу. Као што је познато, први пут у историји ьудског Аруштва ти су се усмови стекли почетком III мименијума пре н.е. у Месопотамији и пре тога времена није бимо ни услова ни потреба за настанак писма. И зато већ из тог размога не делују реално покушаји неких стручњака Аа докажу постојање писмености у неким преисторијским археолошким културама. Такве су идеје изнете у вези са знацима једноставних апстрактних кинија на керамици неолитске винчанске културе из средине $\mathrm{V}$ мименијума пре н.е., као и њима типолошки сличних знакова кинеске Јанг Шао културе из VI мименијума пре н.е., који пре могу бити знаци својине или обреАно-магијске „чрте и резе” него знаци писма (Станишић 2002: 44). И док је проблематика Јанг Шао знакова остала углавном у границама синологије (исту тврдњу понавља и Јин Бинјонг, али одбацује Вилијам Болц - Binyong 1997: 2; Boltz 1996: 191), дотме су винчански знаци послужими Марији Гимбутас као доказ да је доиндоевропска „староевропска” култура, чије је откриће и реконструкција највећим делом њена заслуга, у суштини била цивимизација коју је одмиковала и сопствена писменост. У том циљу она је винчанске знаке, које она зове „староевропским”, чак упоредила с четири хиљаде година млађим егејским кинеарима (Gimbutas 1991), што је наишло на оправдану критику (Daniels 1996: 21-22). ${ }^{10}$

Још већу популарност постигла је 80-их година Аениза Шмант-Бесерат теоријом о „токенима” - идејом да од преисторијских рачуноводствених знакова из VIII мименијума пре н.е. са простора северне Месопотамије потиче скоро пет хиљада година ммађа месопотамска писменост (Schmandt-Besserat 1992; в. Бугарски 1996: 39; ИАиевски 2001). Нико, иначе, не оспорава тврдњу да су ти апстрактни претписмени знаци могми имати бројну вредност, Аакме Аа су

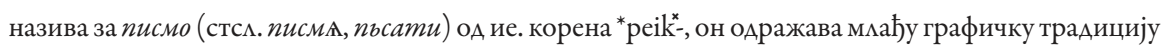
„шарања, бојења, украшавања”, као у митав. piešti, герм. рунском faibido, стина. piṁ́áti, грч. токкілос'шарен, пастрмаст' (уп. Этимологический словарь славянских языєков, 3, 13, Москва 1987: *buky; *kъniga. W. P. Lehmann, A Gothic etymological dictionary, Leiden - E. J. Brill 1986: maljan; М. Фасмер, Этимологический словарь русского языка, Москва 1986: буква; книгга; писа́ть).

${ }^{10}$ Уп. такође мишњење археолога о псеудонаучној аргументацији у вези с геометријском орнаментиком и апстрактним симболима тзв. винчанског писма (Палавестра 2010: 252). Ни најновији радови следбеника европоцентричне хипотезе Марије Гимбутас (нпр. Haarmann 2002, Иванов 2009) не Аају довољно убедњивих доказа за тврдњу да је најстарија писменост могла бити рођена у неолитској култури балканског Подунавња, пре свега зато што настанак писмености мора имати историјски ослонац и да нађе подршку у друштвено-економским структурама које се рађају с појавом цивилизације (Сухачев: 33 ). 
бројеви могми да претходе појави писма (уп. такође ИАиевски 2001: 41-47), ами је спорна њена претпоставка како је упрошћени геометријски облик ових знакова могао да послужи као идеја за рану клинасту стилизацију знакова сумерског писма, што је временом доживело оправдане критике (Daniels 1996: 22-23; Robinson 2007: 60). Као што је добро познато, у основи кминастих знакова налазе се цртежи и конкретан цртежни карактер најстаријих знакова ове писмености сведочи о њеној вези с реалијама месопотамске цивилизације, а не с апстрактним знацима, који се хиљадама година нису мењали, зато што се не односе на Аруштвену, него на једну апстрактну могичку делатност.

Тумачење апстрактних преисторијских знакова као писмених знакова пренебрегава чињеницу да упрошћени апстрактни облик представља хронолошки млађу фазу у еволуцији писма, којој у скучају аутохтоне писмености увек претходи цртежно писмо. ОАсуство цртежне фазе сведочи о томе Аа је ту реч о типолошки разАичитим појавама које припадају разАичитим раздобњима ьудског Аруштва, о неразмиковању писма и цивимизације оА преисторијских култура и њима својствених знаковних система.

У намери да одбрани хипотезу о писменом карактеру винчанских знакова, немачки мингвист ХарацА Хаарман био се помемички осврнуо на јеАан оА кьучних постулата науке о писму - о месту и улози цртежа у развоју писма (1998: 71-72). По том је постулату управо цртеж, а не било какав апстрактан знак, био првобитни знак писма Аа у основи сваког писма кежи цртеж, убедљиво сведочи цртежни карактер свих аутохтоних писмености света, почев оА разних домородачких заједница на племенском ступњу развоја, па до чињенице Аа су писмености свих старих цивилизација биме цртежне. Неоспорна је чињеница, међутим, да у свим старим цртежним писменостима постоје и апстрактни знаци који нису настали каснијом стилизацијом првобитних цртежа. Придајући посебан значај тој чињеници, Хаарман је покушао Аа оспори могућност јасног разграничења између иконичких и апстрактних знакова и да релативизује постулат по којем се у основи писма налази пре свега цртеж. Посреди је неспоразум који је разрешио такође Гелб својом поАелом на писмене знаке и симболе, која се често превиђа. Овим Аругим називом Гелб је именовао апстрактне ванјезичке елементе који стога нису саставни део графичког система, али су зато неизоставни део „писма у правом смислу речи”, чија је првобитна функција била пре свега рачуноводствена (Sampson 1987: 50; Fischer 2001: 22-23; Сухачев 2010: 40).

Расправа о статусу ових апстрактних праисторијских знакова допринела је у суштини бољем разумевању комуникативне улоге симбола у развоју пи- 


\section{Вана С. Станишић}

сма. За разАику оА „предметног писма”, ово је ипак некакво писмо - среАство графичке комуникације које је, као у скучају „чрта и реза” вршимо пре свега обредну функцију - служицо за гатање и бројање. Апстрактна симболика знакова поменутих археолошких култура могла би се разумети опет као својеврсна вертикална комуникација - обредна комуникација одговарајуће заједнице с небеским симама. Аа би добима и хоризонталну димензију - Аа служи за комуникацију унутар заједнице - треба да се организује у реченице, а то је омогућио цртеж (уп., нпр., ране сумерске пописне таблице). Цртеж је, Аакле, омогућио комуникацију у времену и простору - јер преноси поруку која се и данас може прочитати (разумети) и зато је с њим рођено писмо у правом смислу речи. Он и буквално потврђује како је писмо слика одређене културе. ОАсуство цртежне фазе у систему знакова неолитских култура свеАочи како је ту реч о типолошки разцичитим појавама које припадају разцичитим раздобьима ьудског Аруштва, о неразликовању писма (у правом смислу речи) и цивилизације од праисторијских култура и њима својствених знаковних система.

Међутим, сам по себи, цртеж није разграничио историју од праисторије, нити је раздвојио цивилизацију оА културе - пиктографије северноамеричких Индијанаца или појединих афричких племена сачињене су од истих елемената оА којих су биле и писмености мезоамеричких цивикизација или Аревног Египта. Па ипак, упркос својим уметничким дометима, првобитни цртежи носими су пре свега ритуанну поруку. Цртеж, стога, није разграничио историју оА праисторије својом појавом, него својом функцијом - укьучењем у већ постојећи графички систем, који је имао одређену комуникативну функцију. Оно што су поборници неолитске писмености уистину открили јесте најстарији графички систем, који се по својој природи и намени највероватније сводио на „чрте и резе”. КаАа је у такав систем укьучен цртеж, добијен је графички систем који се може прочитати, који поруку преноси и вертикално и хоризонтално.

\section{Аитература}

1. Амирова, Т. А. (1977), К истории и теории графемики, Москва: Наука.

2. Бугарски, Ранко (1996), Писмо, Нови Сад: Матица српска.

3. Гамкрелидзе, Тамаз В. (1989), „Происхождение и типология алфавитной системы письма. Письменные системы раннехристианской эпохи”, Вопросы языкознания 5, Москва. 
4. Гельб, И. Е. (1982), Опыт исследования письма, Москва: Радуга [Gelb I.J., $A$ Study of writing, Chicago: Chicago University Press 1952; 1963].

5. Арукер, Јохана (2006), Алфабетски лавиринт. Слова у историји и имагинацији, Нови СаА: Stylos [J. Drucker, The Alphabetical Labyrinth. The letters in history and imagination, London: Thames \& Hudson Ltd, 1995].

6. Журавлев, В. К. (1982), Внешние и внутренние факторы язьковой эволючии, АН СССР, Москва: Наука.

7. Журавлев, В. К. (1986), Аиахроническая фонология, Институт языкознания, Москва: Наука.

8. Зиндер, Аев Р. (1987), Очерк общей теории письма, Аенинград: Наука.

9. Иванов, В. В. (2009), „О Аревнебалканской письменности”, Мартенища, Мărțişor,

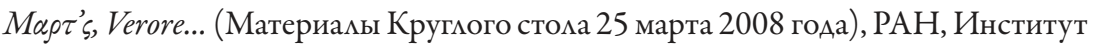
славяноведения, Москва, 13-23.

10. Иииевски, П. Хр. (2001), Појава и развој на писмото. Со посебен осврт кон почетоците на словенската писменост, Скопје: МАНУ.

11. Кондратов, А. М. (2007), Писмена мертвые иживые, Санкт-Петербург: Авалон - Азбука кмассика.

12. Палавестра, Александар (2010), „Измишљање традиције: 'винчанско писмо”, Етноантрополошки проблеми н.с., 5, 2, Београд: ОАењење за археологију Филозофског факултета Универзитета у Београду, 239-258.

13. Станишић, Вања (2002), „Типолошка проблематика класификације система писма", Зборник Матище српске за филологију и лингвистику, XLV/1-2, Нови CaA, 41-57.

14. Станишић, Вања (2003), „Неки основни појмови науке о писму”, Научни састанак слависта у Вукове дане, 32/3 (11-15. 9. 2002), БеограА, 255-261.

15. Станишић, Вања (2009), „Писмо као 'визуелни говор' и пробкем његовог Аефинисања", Научни састанак слависта у Вукове дане, 38/3 (4-7. 9. 2008), БеограА, 81-90.

16. Сухачев, Н. А., (2010), Экскурсы в историю письма. Знак и значение. Издание второе, Москва: Издательство $\Lambda$ И (URSS).

17. Binyong, Yin (1997), Modern Chinese characters, Beijing: Sinolingua.

18. Boltz, William (1996), „Early Chinese Writing”, The World's Writing Systems (P. T. Daniels, W. Bright, eds.), Oxford: Oxford University Press, 191-199.

19. Calvet, Louis-Jean (1996), Histoire de l'écriture, Paris: Plon.

20. Cardona, Giorgio R. (1986), Storia universale della scrittura, Milano: Mondadori.

21. Coulmas, Florian (1986), The Writing Systems of the World, Oxford: Blackwell Publishers. 
22. Coulmas, Florian (2003), Writing Systems. An introduction to their linguistics analysis, Cambridge: Cambridge University Press.

23. Coulmas, Florian (2009), „Evaluating merit - the evolution of writing reconsidered”, Writing Systems Research, 1, 5-17.

24. Daniels, Peter T. (1990), „Fundamentals of grammatology”, Journal of the American Oriental Society, 110, 27-31.

25. Daniels, Peter T. (1996), „Grammatology”, The World's Writing Systems (P. T. Daniels, W. Bright, eds.), Oxford: Oxford University Press,1-18.

26. Daniels, P. T., Bright, W., eds. (1996), The World's Writing Systems, Oxford: Oxford University Press.

27. DeFrancis, John (1989), Visible Speech: The Diverse Oneness of Writing Systems, Honolulu: Hawaii University Press.

28. Diringer, David (1968), The Alphabet: A Key to the History of Mankind, New York: Philosophical Library.

29. Diringer, David (1985), „A escrita”, Historia Mundi 12, Editorial Verbo [D. Diringer, Writing, Cambridge University Press 1962].

30. Fischer, Steven (2001), A History of Writing, London: Reaktion Books.

31. Friedrich, Johannes (1966), Geschichte der Schrift, Heidelberg: Carl Winter.

32. Gaur, Albertine (1984), A history of writting, London, The British Library.

33. Goody, Jack (1986), The logic of writing and the organization of society, Cambridge: Cambridge University Press.

34. Gimbutas, Marija Alseikaite (1991), The Civilization of the Goddess: The World of Old Europe, San Francisco: Harper San Francisco.

35. Haarmann, Harald (1991), Universalgeschichte der Schrift, Frankfurt: Campus.

36. Haarmann, Harald (1995), Early civilization and literacy in Europe: an inquiry into cultural continuity in the Mediterranean world, Berlin: Walter de Gruyter \& Co.

37. Haarmann, Harald (1998), „Writing technology and the abstract mind”, Semiotica, 122, 1/2, 69-97.

38. Haarmann, Harald (1999; 2002), „On the Nature of Old European Civilization and its script", Studia indogermanica Lodziensia, 2, 123-133.

39. Hamann, Byron Ellsworth (2008), „How Maya Hieroglyphs Got Their Name: Egypt, Mexico, and China in Western Grammatology", Proceedings of the American Philosophical society, 152, 1, 1-68.

40. Harris, Roy (2000), Rethinking Writing, Bloomington: Indiana University Press.

41. Justenson, John S., Stephens, Laurence, D. (1993), „The evolution of syllabaries from alphabets: Transmission, language contrast and script typology", Die Sprache 35/1993, $2-46$.

42. Mair, Victor H. (1996), „Modern Chinese Writing”, The World's Writing Systems (P. T. Daniels, W. Bright, eds.), Oxford: Oxford University Press, 200-207. 
43. Martin, Henri-Jean (1990), Storia e potere della scrittura, Roma [Histoire et pouvoirs de l'écrit, Perrin, Paris 1988].

44. Olson, David (1988), ,The evolution and typology of writing systems”, Encyclopaedia Britanica, 19: 1034, 10: 658.

45. Olson, David (1997), „On the relations between speech and writing”, Writing development (C. Pontecorvo, ed.), Amsterdam - Philadelphia: PA John Benjamins, 3-20.

46. Pulgram, Ernest (1976), „The typologies of writing systems”, Writing without letters, Munchester University Press, 1-28.

47. Robinson, Andrew (2007), The Story of Writing. Alphabets, Hieroglyphs \& Pictograms, London: Thames \& Hudson Ltd.

48. Rogers, Henry (1995), „Optimal orthographies”, Scripts and literacy, 19-31.

49. Rogers, Henry (2005), Writing systems: a linguistic approach, Oxford: Blackwell Publishing.

50. Sampson, Geoffrey (1987; 1985), Writing systems, London: Hutchinson.

51. Schmandt-Besserat, Denise (1992), Before Writing I, From Counting to Cuneiform, Austin: Texas University Press.

52. Žagar, Mateo (2007), Grafolingvistika srednjovjekounih tekstova, Zagreb: Matica hrvatska.

\section{ПРОСТРАНСТВО И ВРЕМЯ В СТРУКТУРЕ ПИСЬМА}

\section{Резгме}

В сику своей Авусторонней природы письмо находится в тесной связи, как с языком, так и с культурной историей. Цивилизационное значение письма, в этом смысле, хорошо имлюстрирует заявление Питера Ааниельса о том, что: “человеческое общество определяется посредством языка, а цивилизация опредемяется через письмо" (Daniels 1996: 1). Из этого можно не только утверждать, что язык первичен, а письмо вторично, но и то, что письмо помимо обладания коммуникативной функцией является и одним из важнейших отличий цивимизации.

vanjast61@gmail.com 